\title{
Discontinuous elements in morphology
}

\author{
Ingeborg M Kosch \\ Department of African Languages, University of South Africa, \\ PO Box 392, Pretoria, 0003, South Africa. \\ e-mail: koschim@unisa.ac.za
}

\begin{abstract}
This article probes into the nature of discontinuous elements in the morphology of some African languages, but in Northern Sotho in particular. The discussion is conducted against the backdrop of two principles which are generally held to be characteristic of 'pure' agglutinative languages, namely the principle of invariance of morphemes and the principle of a one-to-one matching between a form and a meaning. Agglutinating languages such as the African languages, including Northern Sotho, display deviations from these ideal agglutinative norms. The deviations may assume various forms, but in this article the scope is narrowed down to instances where the deviations manifest as 'discontinuous' or 'interrupted' elements. Terms such as infixes, circumfixes and extended exponents, which form an integral part of the discussion, are elucidated.
\end{abstract}

\section{Introduction}

The African languages deviate to some extent from the following two principles which are generally held to be characteristic of the 'pure' agglutinative type:

- the 'invariance of morphemes' principle, and

- the 'one form - one meaning' principle.

Deviations from these norms can take on many forms, but this article focuses specifically on deviations which display elements which could be regarded as 'discontinuous' or 'interrupted' in one way or another.

\section{Principle 1: 'Invariance of morphemes'}

This principle has also been termed the 'no alteration at morpheme boundary' principle by Hagège (1990:297). It stipulates that, for ideal agglutinating languages, morphemes should consist of the same phoneme sequence in all circumstances (or at least display forms which are phonologically motivated) and maintain clear linear morpheme boundaries. According to Comrie (1989:50), instances in which the variability of morpheme shape is completely predictable in terms of general phonological rules of the language in question should, presumably, 'not be considered violations of invariance, since the variability of the morpheme is an inevitable consequence of other rules of the language.' The violation of Principle 1 will for the most part be discussed with reference to the realizations of the perfect tense suffix (also termed the past tense suffix in some grammars).

\section{Allomorphs of the perfect tense suffix}

Depending on the phonological environment, the following allomorphs can be identified as realizations of the perfect tense suffix in Northern Sotho: -ilê, -itšê, - -mê, -nê or the shortened form -e, e.g.

(1)

$\begin{array}{ll}\text {-leka: -lekilê } & \text { 'tried' } \\ \text {-lesa: -lesitšê } & \text { 'left' } \\ \text {-rêma: -rêmmê } & \text { 'chopped'(also -rêmilê) } \\ \text {-gana: -gannề } & \text { 'refused' } \\ \text {-bôna: -bône } & \text { 'saw' }\end{array}$


The regular or 'default' form of the suffix is -ilê as in the first example in (1) above. The suffix -itše has a phonological rationale, because it occurs predictably after a sibilant, while the remainder of the suffixes may only be diachronically explainable. Since phonological explainability is a matter of degree, it is difficult to state clearly whether the allomorphs $-m \hat{e},-n \hat{e}$ and $-e$ should be seen as violating the principle of invariance of morphemes or not. What would at least count in their favour towards agglutination is the fact that they each occupy the slot usually reserved for the perfect tense suffix, in other words the boundary between the root and the suffix is easily recognized.

More complicated, and definitely violating the principle of invariance, are perfect tense forms in which there is fusion between the root and the perfect tense suffix, e.g.

$\begin{array}{lll}\text { (2) Root } & \text { Verb stem in perfect tense form } \\ \text {-apar- } & \text {-apêre } & \text { 'got dressed' } \\ \text {-swar- } & \text {-swêre } & \text { 'caught' } \\ \text {-rwal- } & \text {-rwêle } & \text { 'carried' }\end{array}$

From the examples in (2) above it is clear that the perfect tense suffix has left a trace in two places, namely root internally in the form of a vowel change, and stem finally in the form of the vowel $-e$. In Northern Sotho this modification is restricted to certain verb stems, i.e. the rule does not always apply in all cases where the vowel ' $a$ ' precedes the final consonant (cf. -bala: -badilê and not *-bêle 'read'; -rôbala: -rôbêtše and not *-rôbêle 'went to sleep', i.e. 'be asleep'). Schematically the range of influence of the perfect tense suffix could be represented as follows:

Diagram 1: The range of influence of the perfect tense suffix

morphemic level:
morphophonemic level:
phonemic level:

At this point of the discussion reference to a study on Zulu perfect tense forms would seem appropriate, since it also sheds light on what has taken place in the Northern Sotho perfect tense form in Diagram 1 above. For similar examples in Zulu, Beuchat (1966:62) recognizes a discontinuous allomorph for the perfect tense suffix. In Zulu verb stems in which an ' $\mathrm{a}$ ' precedes the final consonant, i.e. ' $\mathrm{aC}$ ', this vowel will be changed to ' $\mathrm{e}$ ' under the influence of the first vowel ' $\mathrm{i}$ ' of $-i l e^{1}$. Beuchat (ibid.) represents the process as follows: ' $-\mathrm{aC}-+-\mathrm{i} . . \mathrm{e}>-\mathrm{eCe}$ '. We notice from this representation that what remains of the basic suffix -ile is the discontinuous allomorph $/-i$... e/. Beuchat offers no explanation regarding the disappearance of the segment ' $l$ ', but its deletion is not an isolated occurrence, as will become evident further on (cf. example (8)).

The following Zulu examples flesh out the process ' $-\mathrm{aC}-+-\mathrm{i} . . \mathrm{e}>-\mathrm{eCe}$ ' as indicated by Beuchat, showing clearly that the final consonant $(C)$ has penetrated into the perfect tense suffix. The latter occurs as an interrupted morpheme as it has left a trace to the left as well as to the right of the final consonant.
(3) -fudumal- $+-i \ldots e$ :
-fudumele
'became warm'
-bonan- + -i...e:
-bonene
'saw each other'
-phakam- + -i...e:
-phakeme
'became elevated' 
In Northern Sotho, not only root internal vowels may be affected during the affixation of the perfect tense suffix, but consonants may also undergo changes, e.g.

(4) -dula: -dutšê

'sat'

-tlala: -tlêtše

'became full/be full'

-senya: -sentšê

'destroyed'

The identification of an allomorph for the perfect tense suffix in more drastic cases involving consonant modifications as in (4) above becomes tricky. In this case we may follow one of two possible analyses: the final vowel (-ê or $-e$ ) may be segmented off and regarded as that portion which corresponds with the perfect tense suffix, while the remaining part is regarded as an allomorph of the respective root (i.e. -dul-: -dutš-; -tlal-: -tlettš-; -seny-: -sentš-). The other possibility is to regard the whole perfect tense verb stem as one fused, unsegmentable morph consisting of two morphemes (root plus perfect tense suffix). The reasoning behind this would be that in e.g. -tlêtše "became full' the palatal consonant $/ \mathrm{t} /$ / is just as much part of the root as it is of the suffix. The consonant modification as well as the accompanying root internal vowel change and the contraction of the perfect tense suffix to stem final vowel $-e$ are thus all instrumental in expressing the property 'perfect tense', cf.

Diagram 2: The perfect tense verb stem as one fused, unsegmentable morph

$\begin{array}{l}\text { Morphemic level: } \\ \text { Morphophonemic level: }\end{array}$-tlal- $\}+\{$-ilê $\}$

With all the variables involved, it is clear that it becomes a complicated matter to postulate any sensible morph for the perfect tense suffix. Finding the most appropriate method for the description and analysis of examples which have no clear-cut boundaries between their morphs has been the subject of innumerable volumes in linguistic works internationally. For the Sotho and Nguni languages Louw (1984:232) is of the opinion that perfect tense forms such as -dutšê, -tlêtše and -sentšê should be treated as uninterrupted units:

A precise, discrete morpheme for the perfect or causative cannot be identified in the examples given for Nguni and Sotho. Examples, like these, are best to be explained in terms of fused exponence .... This term is used for morphemes which have been welded so closely together that they have lost their original phonological identity.

\section{Discontinuous morphs created by infixation}

The continuity of a morpheme may be disrupted by the insertion of another morpheme, normally an affix. Linguistically the process whereby one morpheme is inserted into another is known as infixation and the affix which is inserted is an infix. Most commonly an infix will interrupt a root, but this is by no means limited to roots. One affix can also intrude into another affix. Examples where one morpheme is able to intrude into another, thus breaking up its continuity, are rare in the African languages.

According to Okoth Okombo (2000:204) infixation occurs in Kiswahili when -i- is inserted into the root of the singular noun to form the plural:

(5) class 11: abdi 'God's messenger' (singular)

class 12: abidi 'God's messengers' (plural form of 11) 
There exists an apparent anomaly in the morphological descriptions of African languages in that some deny the existence of infixes (cf. Krüger, 1958:352: 'Bantoetale het nie infigale morfeme nie.'), while others make use of the term infix freely. This can be ascribed to two different interpretations of infixes:

- The first interpretation regards infixes as affixes which are inserted into, rather than between, other morphemes. This appears to be the interpretation which is generally attached to infixes on the international linguistic scene. A definition which, to my mind, quite appropriately expresses this view within the spirit of the present discussion of discontinuous elements is the following: an infix is an affix

which interrupts another morph and thus causes this morph to occur discontinuously. It is important to note that a true infix always interrupts another morph; it is not sufficient for it to merely be wordinternal. In most cases of infixation, the interrupted morph is a root, but some cases are known where an infix interrupts another affix - a prefix or a suffix - so interruption of a root should not be taken as a necessary part of the definition of this type of affix. (Lockwood, 1993:19)

If we accept this definition, there will hardly be any occurrences of infixation in the African languages.

- According to the second interpretation an infix is any affix which may be inserted between two other morphemes, e.g.

(6) go di rêkiša 'to sell them'

where $d i$ - is an affix which occurs as an infix between the infinitive prefix go- and the verb root -rêk- 'buy', while $-i \check{s}$ - is an affix functioning as an infix between the verb root -rêk- and the verb suffix $-a$. This usage of the term infix seems to be a particularized one adopted in the description of some African languages.

Where an infix has been interpreted according to sense (a), the only environment which is generally considered for Northern Sotho as possibly exemplifying the occurrence of this type of affix, is described as follows by Louwrens (1994:8):

Infix: ... A possible example of such intrusion of one morpheme into another is where the passive extension -iw- (read -w-) splits up the past tense suffix -ilê... (parenthesis IMK).

(7) baithuti ba rutil-w-ê ke moêng

'the students were taught by the visitor'

The perfect tense suffix has variously been labelled or analyzed by grammarians in the Sotho languages as indicated below:

-ilê (suffix) Z Ziervogel et al. (1979:31), Tucker (1969:119), Poulos \& Louwrens

$(1994: 214)$

$-i l \hat{e}$ (extension)

Lombard et al. (1985:117)

$-i l$ - (suffix)

Prinsloo et al. (2000:230)

$-i l$ - (suffix) plus -e (ending)

Krüger (1973:53)

$-i l-($ extension) plus $-\hat{e}$ (suffix)

some Bantuists (according to Lombard et al., 1985:117)

Some grammarians regard -ile as consisting of two morphemes, namely -il-and - $\hat{e}$. Others regard it as a single morpheme, but acknowledge that it is a discontinuous morph, because its phoneme sequence may be broken up by the passive suffix $-w$-. Lombard et al. (1985:117) probably summarize the generally accepted viewpoint best when they say:

The occurrence of these two elements ... is mutually obligatory, i.e. if the -il... occurs, it must be followed by ... $\hat{e}$, in other words $-i l . .$. cannot be followed by $-a$ as in the case of other extensions. Therefore it is regarded as a single morpheme here, but an interrupted morpheme, viz. -il...e. It must be regarded as interripted because the $-i l . .$. may be separated from ...e by the passive extension. 
Why, one might ask, is this kind of interruption of morphemes only observed in the case of the perfect tense suffix and the passive suffix and not between any of the other verbal suffixes? Two possible reasons could be considered. Firstly, the phonological make-up of the suffixes involved is conducive to the process: the passive suffix, consisting of only a consonant $-w$ - in the short form, can take up a position between the $-i l$ - and the final $-\hat{e}$ without disrupting the regular phonological pattern. According to Katamba (1993:280) there may be a stipulated order for morphemes morphologically, but phonological considerations may eventually be the sole determinant of the order of morphemes in a word. Should we place the perfect tense suffix in stem final position, a phonologically acceptable form will be created, but it will be ungrammatical (*ba rutwile 'they were taught'). Reversing the positions will result in a phonologically and grammatically unacceptable structure (*ba rutilêw). The passive suffix must yield to the perfect tense suffix, since every verb stem needs to end on a vowel (or syllabic sound) and the vowel can only be provided by the perfect tense suffix in this case. Quoting Meussen (1959), Katamba (1993:281) states that ' $\ldots$ in Bantu languages, any monophone verbal suffix, simply because it is monophone (i.e. one that is realised by a single sound e.g.,$y u$ or $w$ ), tends to appear after all other suffixes - except the final vowel representing the basic verbal suffix.' The second consideration as to why these suffixes appear combined as they do may be related to the function which they perform in the verb. Masiea (1970:67) says the passive 'is always shifted to the end' because it cannot form a derivative of its own, and 'because it is a voice in contradistinction to the active. It is used mostly when the subject and object change places but not the meaning - this does not apply to the other derivatives!' Both the perfect tense suffix and the passive suffix perform a grammatical function, i.e. the former indicates 'tense', while the latter indicates 'voice' as a grammatical category. Grammatical affixes are generally known to claim more peripheral positions in a word, while derivational affixes, which contribute to the lexical content of the word, tend to occur closer to the root. In the case under investigation we have two grammatical affixes which are in competition for the last position of the word, as it were. One might speculate that the rivalry between the two suffixes for word-final position could possibly have been the trigger for the discontinuity of the perfect tense suffix.

In Zulu the passive suffix $-w$ - may also interrupt the perfect tense suffix. Unlike in the Sotho languages, however, the combination of the two suffixes realizes as -iwe and not as -ilwe, cf. Ziervogel et al. (1967:106): 'in the long perfect stem the $-l$ - of the perfect suffix has been discarded, i.e. -iwe and not *-ilwe', e.g.

(8) zonke izinkomo zithengisiwe 'all the cattle have been sold'

Poulos and Msimang (1998:188) refer to -iw- in Zulu as a formative occurring in the long form of the perfect. The term formative conceals the fact that the two components belong to two different morphemes, i.e. $-i$ - is part of the perfect tense suffix, while $-w$ - represents the passive suffix. Beuchat (1963:159) identifies the allomorph for the perfect tense suffix in examples such as the one in (8) above as follows:

The allomorph /-i...e/ is used with passive-extended radicals when no adjunct follows the verb. In this case the passive extension allomorph /-w-/ occurs between the two members of the discontinuous allomorph, so that /-iwe/ results.

The dots between $-i$ and $-e$ in the above quotation indicate the position taken up by the passive suffix as 'infix'. It is interesting to note that the cause of the discontinuity in example (8) is not the same as in examples (2) (Northern Sotho-apêre, -swêre, -rwêle) and (3) (Zulu-fudumele, -bonene, -phakeme). In example (8) an extra element (i.e. the passive morpheme) is inserted (infixed) into another morpheme, while in the case of examples (2) and (3), the interrupting element is a consonant (' $l$ ', ' $n$ ', ' $m$ ', ' $r$ ' etc.) which is not newly introduced into the stem, but which was already part of the root before it was inflected for tense.

\section{Discontinuity in concordial elements}

There is yet another sense in which the term 'discontinuous' has been applied in relation to certain morphemes in an African language. For Swahili, Harris (1945:124) identifies a 'complicated example of discontinuous repetitive morphemes'. He points out that the class prefixes have discontinuous forms, whereby he refers to the sets of different 
concordial morphemes which are generated by class prefixes. The different agreement morphemes belonging to a particular noun class are positional variants, i.e. their form is determined by the context and they may or may not display a phonological resemblance with the original class prefix, $\mathrm{cf}$.

... these morphemes are discontinuous and ... the discontinuity consists in the repeating of the initial (or of a substitute for it) in stated positions throughout a certain domain. (Harris, 1945:127)

Within our descriptional framework, we could say that concordial morphemes violate the principle of 'invariance of morphemes'. The prefix mo- of class 1 in Northern Sotho, for example, generates phonologically dissimilar agreement morphemes in different contexts: $o$ - or $a$ - (subject concord), $y$ - (concordial prefix in e.g. absolute pronoun, demonstratives), $w$ - (concordial prefix in possessive formative $w a-$ ), etc.

\section{Principle 2: 'One form - one meaning'}

The second principle characteristic of agglutinative languages specifies that each morpheme (or, more specifically, its phonological representation as a morph) be uniquely pairable with exactly one grammatical function or meaning and vice versa, that each function or meaning be expressed by a separate morph. In the ideal situation the internal word-structure is transparent, since the boundaries between the morphs are immediately recognizable, cf. Spencer $(1991: 125 / 6)$ :

... the most natural type of morphology is fully 'transparent', in the sense that every morpheme has one form and one meaning, and every meaning (or grammatical category) corresponds to exactly one form. This relationship is called biuniqueness.

Although instances of unique pairing of morphs and meanings are encountered in agglutinating languages, this is by no means the norm, cf. Anderson (1982:596):

It is true that some languages approach quite closely to the ideal agglutinating type, in which the form/meaning association is completely well behaved; but these appear to be the exception rather than the rule.

Deviations from the one-to-one relationship may manifest in various exponence relations, such as cumulative, fused and extended exponence. In simple terms exponence means 'realization' or 'to make real'. The expression is applied to the relation between an abstract entity and its embodiment in another, concrete entity. The concrete form is regarded as the exponent of the abstract entity. In this article we are particularly interested in extended exponence, since it deals with discontinuous elements.

\section{Extended exponence}

Extended exponence describes the situation in which a single grammatical function or meaning is expressed by two or more morphological markers. These markers or exponents may be adjacent to each other, but they are normally separated from each other by intervening material. A single grammatical function or meaning thus has a discontinuous representation, i.e. its realization shows up in more than one place:

... we often find situations in which a single category is realized in more than one way within a word, that is, where there is many-one correspondence between form and function. This has been referred to as extended or overlapping exponence. (Spencer, 1991:51)

In the African languages the verb displays multiple marking when it expresses a single grammatical function such as 'negative form'. The negative form may be marked overtly by at least two non-contiguous morphs, namely by a negative prefix and a simultaneous modification of the final vowel of the verb stem, e.g. Northern Sotho go se rutê 'not to teach' (positive form: go ruta 'to teach'). For clarity of presentation the morphophonemic level is not included in diagrams 3 and 4. 
Diagram 3: Double marking of negative formation

$\begin{array}{ll}\text { morphemic level: } & \text { infinitive prefix }\}+\{\text { negative }\}+\{\text {-rut }-\}+\{\text { verb suffix }\} \\ \text { phonemic level: } & \text { /yo-/ }\end{array}$

Depending on the mood and tense of the verb as well as the syntactic construction of the sentence, the property negative can have up to five 'realizations', e.g.

(9) Class 1 noun as subject, verb in indicative mood, present tense, no object:

Positive:

motho ó á bapala 'a person is playing'

Negative: motho ga á bapále

'a person is not playing'

(i) the presence of the negative prefix ga-;

(ii) the replacement of the subject concord $\dot{o}$-by $\dot{a}$ - for class 1 nouns;

(iii) the absence of the so-called imperfect tense formative (viz. -á-in $o$ a bapala) in the negative form;

(iv) the substitution of the final $-a$ by $-e$;

(v) the replacement of the second low tone of the verb stem by a high tone, i.e. -bapala >-bapále.

Diagram 4: Multiple marking of negative formation

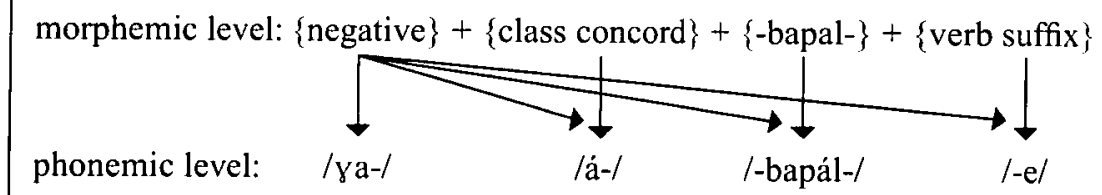

The hortative is signalled simultaneously by a hortative prefix and a change in the terminative vowel of the verb stem from $-a$ to $-\hat{e}$ :
(10)
a ba tsênê
'let them enter'

The relative construction is usually characterized by a relative marker preceding the subject concord and a relative suffix, which is (usually) affixed to the verb stem:
(11a) tau yê e tsomago/ng
'the lion which is hunting'

Cf. also

(llb) tau yê e tlô tsomago/ng 'the lion which will hunt'

or: tau yê e tlôgo tsoma

\section{Circumfixation}

Circumfixation is a type of extended exponence. It describes the simultaneous affixation of a prefix and a suffix to a base to express a single meaning, category or process conjointly. Together the two affixes constitute a special kind of discontinuous affix, i.e. a circumfix. If they are mutually obligatory in all circumstances and the one never occurs without the other they are taken to be a single affix and a discontinuous morph. Circumfixation does occur in the African languages, but more often than not either the prefix or the suffix is dispensable, depending on the circumstance or specific lexical item involved. Spencer (1991:13) points out that the recognition of circumfixes is 
rather controversial, since many linguists would argue that all cases of alleged circumfixation can be reduced (or must be reduced) to suffixation and concomitant prefixation. Only a few examples have been selected below, but they should suffice to illustrate that a single category may have a discontinuous representation in the form of two disjoined morphs.

The process whereby deverbatives are formed requires simultaneous markers in a prefixal and suffixal position. This strategy can be observed in many African languages, e.g.

(12a) Northern Sotho

$\begin{array}{lll}- \text { dir- 'do': } & \text { modiri } & \text { 'worker' (class 1) } \\ & \text { mediro } & \text { 'jobs' (class 4) }\end{array}$

(12b) Zulu

$\begin{array}{lll}\text {-fund- 'learn': } & \text { abafundi } & \text { 'learners' (class 2) } \\ & \text { isifundo } & \text { 'lesson' (class 7) }\end{array}$

In Northern Sotho, examples of true circumfixation, in which a prefix and a suffix are mutually obligatory, appear to be limited to deverbatives. In other languages instances of circumfixation may be encountered in a number of other contexts, e.g. in the locative formation (e.g. Nguni languages) or in certain cases in the diminutive formation (e.g. Venda and Tsonga):

(13) Zulu locative: umuthi 'tree': emthini 'in the tree'

(14) Venda diminutive: mulambo 'river': tshidambwana 'small river'

(15) Tsonga diminutive: murhi 'tree': ximudyana 'small tree'

In Northern Sotho the double marking of the diminutive is very rare. Remnants of this possibly once productive strategy of circumfixation may be found in isolated examples such as mmutla 'hare': kgabutlane 'little hare' (regular mmutlanyana), as well as in certain items such as some colour terms in order to indicate female animals. Some examples which appear in Prinsloo et al. (2000:223) as quoted from Mönnig (1978:169) appear in example (16):

$\begin{array}{lll}\text { Bulls and oxen: } & & \text { Cows: } \\ \text { khulong 'red' } & > & \text { nakhulwana } \\ \text { ntsho 'black' } & > & \text { naswana } \\ \text { hlaba 'red with brown spots' } & > & \text { nahlabana } \\ \text { tšumu 'red with white mark on face' } & > & \text { natšungwana }\end{array}$

In Northern Sotho diminutive meaning and feminine gender are generally marked by either a prefix or a suffix, but not both, e.g. pudi 'goat': putšana 'kid'; tilu 'brown ox/bull with dark brown stripes': tilwana 'brown cow with dark brown stripes'; ngwana 'child': ngwananyana 'girl'; tau 'lion': taugadi 'lioness'; Matsobane (proper name: male): Ramatsobane (proper name: female)'; Sello (proper name: male): Masello (proper name: female).

The examples given above of extended exponence (and circumfixation as a type of extended exponence) exemplify deviations from the agglutinative ideal of a one-to-one relationship between a phonological form and a function/ meaning. In such relationships the number of morphs exceed the number of grammatical functions or meanings in a word or phrase. The grammatical function/meaning is said to be expressed discontinuously if two or more morphs are needed to mark it in different positions in a construction. 


\section{Conclusion}

Northern Sotho displays deviations from the two principles which are generally regarded as characterizing languages of the agglutinative type, namely the 'invariance of morphemes' principle and the 'one form - one meaning' principle. To illustrate such deviations the focus was placed especially on discontinuous representations of morphs and grammatical functions. The violation of Principle 1 (invariance of morphemes) was mainly illustrated with reference to the perfect tense suffix and its combination with the passive suffix. It was shown that the internal phonological stability of the perfect tense suffix can be broken up by certain consonants or by the insertion of the passive suffix. The passive suffix is often quoted as an example of an infix by those African linguists who understand an infix to be a morpheme which is able to split up another morpheme, rendering it discontinuous. Nida (1963:270) states that 'In all true instances of infixation the two parts of the morpheme in which the infix appears together make up a discontinuous morpheme, ...' cf. -il...e in Northern Sotho and $-i \ldots e$ in Zulu. Violations of Principle 2 (one form - one meaning) were illustrated with reference to several examples in which the realization of a single grammatical category, meaning or process is discontinuous, because its expression requires more than one non-contiguous morph which are mutually obligatory in the constructions in which they occur. Both infixation and circumfixation were shown to be processes which result in discontinuous morphological units. Occurrences of infixation are rarer than occurrences of circumfixation in the African languages. Some of the various senses in which the term 'discontinuous' has been applied by different morphologists in the African languages were pointed out during the course of the discussion.

\section{Notes}

1. By convention no circumflex is used on mid-low vowels in Zulu, due to this language having a five-vowel system, as opposed to the seven-vowel system in Northern Sotho, hence -ile in Zulu and not -ile as in Northern Sotho.

2. Only applicable to a limited group of names. $R \boldsymbol{a}$ - usually indicates male names, but in the case of this group, it refers to female names.

\section{References}

Anderson, S.R. 1982. Where's Morphology? Linguistic Inquiry 13(4):585-591.

Beuchat, P-D. 1963. Restatement of the Zulu verb conjugation. African Studies 22(4):137-169.

Beuchat, P-D. 1966. The perfect tenses in Zulu. African Studies 25(2):61-71.

Comrie, B. 1989. Language universals and linguistic typology. $2^{\text {nd }}$ ed. Oxford: Basil Blackwell.

Hagège, C. 1990. Do the classical morphological types have clear-cut limits?, in Contemporary Morphology, edited by W.U. Dressler, H.C. Luschützky, O.E. Pfeiffer \& J.R. Renison. Berlin, New York: Mouton de Gruyter:297-308.

Harris, Z.S. 1945. Discontinuous morphemes. Language 21:121-127.

Joos, M. (ed.) 1963. Readings in Linguistics. $3^{\text {rd }}$ ed. American Council of Learned Societies: New York.

Katamba, F. 1993. Morphology. London: Macmillan Press Ltd.

Krüger, C.J.H. 1958. Opmerkings oor Sotho-morfologie. Koers 25(4 \& 5):345-352.

Krüger, C.J.H. 1973. Some notes on the hierarchy of morphological categories in Tswana nouns and verbs. Essays on Literature and Language presented to Prof. T.M.H. Endemann. University of the North:41-57. 
Lockwood, D.G. 1993. Morphological analysis and description: A realizational approach. Tokyo, Taipei, Dallas: International Language Sciences Publishers.

Lombard, D.P., van Wyk, E.B. \& Mokgokong, P.C. 1985. Introduction to the grammar of Northern Sotho. Pretoria: J.L. van Schaik.

Louw, J.A. 1984. Word categories in Southern Bantu. African Studies 43(2):231-239.

Louwrens, L.J. 1994. Dictionary of Northern Sotho grammatical terms. Pretoria: Via Afrika.

Masiea, J.R. 1970. The order of sequence of verbal extensions in Southern Sotho. Limi 9:64-73.

Nida, E.A. 1963. The identification of morphemes, in Readings in Linguistics, edited by M. Joos. New York: American Council of Learned Societies:255-271.

Okoth Okombo, D. 2000. Building techniques in African languages, in African voices: An introduction to the languages and linguistics of Africa, edited by V. Webb \& Kembo-Sure. Cape Town: Oxford University Press Southern Africa:197-219.

Poulos, G. \& Louwrens, L.J. 1994. A linguistic analysis of Northern Sotho. Pretoria: Via Afrika Limited.

Poulos, G. \& Msimang, C.T. 1998. A linguistic analysis of Zulu. Cape Town: Via Afrika.

Prinsloo, D., Chuwa, A.R. \& Taljard, E. 2000. The lexicons of Africa, in African voices: An introduction to the languages and linguistics of Africa, edited by V. Webb \& Kembo-Sure. Cape Town: Oxford University Press Southern Africa:220-244.

Spencer, A. 1991. Morphological theory. An introduction to word structure in Generative Grammar. Oxford: Blackwell Publishers.

Tucker, A.N. 1969. The comparative phonetics of the Suto-Chuana group of Bantu languages (republication of 1929). Westmead, Farnborough, Hants., England: Gregg International Publishers Limited.

Ziervogel, D., Louw, J.A. \& Taljaard, P.C. 1967. A handbook of the Zulu language. Pretoria: J.L. van Schaik Ltd.

Ziervogel, D., Lombard, D.P. \& Mokgokong, P.C. 1979. A handbook of the Northern Sotho language. Pretoria: J.L. van Schaik. 
Copyright of South African Journal of African Languages is the property of University of Port Elizabeth, Department of African Languages and its content may not be copied or emailed to multiple sites or posted to a listserv without the copyright holder's express written permission. However, users may print, download, or email articles for individual use. 